\title{
まさ土の非排水繰返しせん断強度と 相対密度の評価に及ぼす細粒分の影響
}

\author{
金 佑泰 1 兵動 正幸 $2 \cdot$ 中田 幸男 $3 \cdot$ 吉本 憲正 4 ・野田 翔兵 5
}

1韓国海洋研究院 沿岸開発エネルギー研究部（†426-744 韓国京機道安山市常緑区四2同1270)

E-mail: wootaekim@kordi.re.kr

\begin{abstract}
2正会員 山口大学教授 大学院理工学研究科環境共生系専攻（干755-8611 山口県宇部市常盤台2-16-1）
E-mail: hyodo@yamaguchi-u.ac.jp

3正会員 山口大学教授 大学院理工学研究科環境共生系専攻（†755-8611 山口県宇部市常盤台2-16-1）

E-mail: nakata@yamaguchi-u.ac.jp

4正会員 山口大学助教 大学院理工学研究科環境共生系専攻（†755-8611 山口県宇部市常盤台2-16-1）

E-mail: nyoshi@yamaguchi-u.ac.jp

5学生会員 山口大学大学院理工学研究科環境共生系専攻（干755-8611 山口県宇部市常盤台2-16-1）

E-mail: r003wf@yamaguchi-u.ac.jp
\end{abstract}

\begin{abstract}
2地点から採取したまさ土を対象に一連の非排水繰返し三軸試験を行った。試験結果から得られたまさ 土の液状化強度は，相対密度 $80 \%$ 以下ではほぼ一定であり，相対密度が $100 \%$ 以上で急上昇することが観察 された。これは, JISで規定された最小, 最大密度試験が乾燥状態の試料を対象としているのに対し，ま さ土は細粒分を有し，水中ではコラプスを起こし，さらに圧密により体積収縮するため，緩いまさ土は結 果的にほぼ一様の密度になってしまったためと考えられる。 そこで, 本研究では湿潤試料を対象に最小, 最大密度試験を行い, 新しい相対密度を再定義した。この相対密度と液状化強度との関係をまとめると, 相対密度の変化に対しまさ土も豊浦砂と同様な挙動を示し，細粒分を有するまさ土の液状化強度を相対密 度との関係で説明できることが明らかとなった。
\end{abstract}

Key Words : masado, fines content, compression, undrained cyclic shear strength, relative density

\section{1. まえがき}

まさ土は，粒度分布が良く締固め易いことから各種盛 土材料として頻繁に利用されている。しかし，1995 年の 兵庫県南部地震では六甲山系のまさ土で埋立てられたポ ートアイランドや六甲アイランドなどの人工島で液状化 が発生し港湾施設など ${ }^{11-3)}$ に大きな被害を与えた。まさ 土は西日本に広く分布し，礫からシルトに至る広範な粒 度組成から成り，粒子自体が脆弱で破砕し易い材料であ るため破砕性土と呼ばれ，これまで「特殊土」として取 り扱われてきた．破砕性土は，外力が加わることで粒子 全体または一部が破砕し，それにより圧縮沈下や地盤支 持力，せん断抵抗の低下をきたすことがある ${ }^{4,5}$. . 圧縮 特性は，外力による圧縮変形だけではなく，雨水の浸透 や地下水位の上昇による水浸特性との関連もある. 不飽 和状態の地盤に雨水などが浸入することによってサクシ ョンの低下によるコラプス沈下を起こし，構造物の不同
沈下などを起こすことも懸念されるの, 。このような圧 縮特性や水浸特性は，土の風化度，細粒分含有率，間隙 比などに左右される ${ }^{81-10)}$.

まさ土は細粒分を含むが，非塑性の細粒分を有する場 合には便宜上砂と同様の方法で相対密度を求めて評価さ れることが多い，既往の研究で，まさ土の液状化強度は 相対密度 $D_{r}=50 \sim 80 \%$ 程度の変化に対しさほど変化がな いという報告がある ${ }^{1)}$,9) 11)。一方では，相対密度が 100\% を越えると液状化強度は増加するという結果も得られて いる ${ }^{8)}$ 12)，砂の相対密度を規定する最小，最大密度試験 は JIS A 1202-199913)によって定められているが，その適 用は細粒分含有率 $5 \%$ 以下の砂とされている。 それ以上 の細粒分を有する土には規格がないまま JIS 法が援用さ れているのが現状である．まさ土の液状化強度を的確に 評価する上で， $N$ 值と相対密度，相対密度と液状化強度 の関係を考えた時に，まさ土のように相対密度が 100\% を超えないと液状化強度が高くならないような材料では, 
表-1 試料の物理的性質

\begin{tabular}{|c|c|c|c|c|c|c|c|}
\hline sample & $\mathrm{FC} \%$ & $\rho_{5}\left(\mathrm{~g}^{\prime} / \mathrm{cm}^{3}\right)$ & $\mathrm{e}_{\mathrm{mFx}}$ & $\mathrm{e}_{\mathrm{min}}$ & $\Delta \mathrm{e}$ & Uc & LI \\
\hline \hline \multirow{2}{*}{ P.I.Masado } & 13 & 2.624 & 0.967 & 0.491 & 0.476 & 20.81 & 0.932 \\
\cline { 2 - 8 } & 0 & 2.619 & 0.967 & 0.512 & 0.455 & 4.67 & 0.716 \\
\hline \multirow{2}{*}{ Wwakuni Masado } & 11 & 2.673 & 1.042 & 0.616 & 0.426 & 6.66 & 1.63 \\
\cline { 2 - 8 } & 0 & 2.632 & 0.935 & 0.510 & 0.425 & 2.672 & 2.257 \\
\hline Toyoura & 0 & 2.64 & 0.973 & 0.635 & 0.338 & 1.33 & 0.327 \\
\hline
\end{tabular}

砂と同様の方法では適切な評価が出来ないため，相対密 度の規定を再評価することは極めて重要と考えられる。 液状化強度を $N$ 值から直接評価する方法もあるが，まさ 土についてのデータベースはほとんどなく， $N$ 值は相対 密度に結び付けて使用されることが多いことから，相対 密度を明確にすることは重要なことと考えられる.

本研究では，まさ土の諸特性(物理的特性，破砕性， 締固め特性など)に着目し，山口県岩国市，兵庫県神戸 市より採取した乱したまさ土を対象とし，最小，最大密 度試験の方法について検討し，まさ土に対する的確な相 対密度の評価と液状化強度に及ぼす細粒分の影響を調べ た.

\section{2. 試料及び実験方法}

本研究では神戸市の人工島ポートアイランドで採取し たまさ土（P.I. Masado）と山口県岩国市愛宕山で採取し たまさ土（Iwakuni Masado）の2 種類の試料を用いて実験 を行った．実際には原位置でのまさ土は礫分を含んでい たが，土全体のマトリックスは，砂分およびシルト分が 支配しているという判断と供試体寸法の制約から，実験 には両試料とも砶分を除去した $2 \mathrm{~mm}$ ふるい通過分を用 いた．本論文ではこれらを原粒度まさ土と呼ぶ。また， 細粒分を除去したまさ土についても実験を行った.さら に比較材料として，シリカ砂である豊浦砂についても実 験を行った. 図-1に実験に用いた試料の粒度を示す. Iwakuni Masado の方が P.I. Masado に比べより細かい砂分を 含み，いずれも $10 \%$ 強の非活性の細粒分を含んでいる.

表-1 に用いた試料の物理的性質を示す．表中に，JIS 法 で調べた最小，最大間隙比を示しているが，最大間隙比 と最小間隙比の差がまさ土は豊浦砂に比べて大きいこと がわかる。また細粒分を含むまさ土の最大密度は，P.I. Masado で $\rho_{\text {dmax }}=1.760 \mathrm{~g} / \mathrm{cm}^{3}$, Iwakuni Masado で $\rho_{d \max }=1.654 \mathrm{~g} / \mathrm{cm}^{3}$ であったが, Inagaki ら ${ }^{14)}$ により 1995 年兵庫県南部地震 直後の神戸六甲アイランドから採取された凍結試料では, 乾燥密度が $\rho_{d}=1.7 \sim 2.1 \mathrm{~g} / \mathrm{cm}^{3}$ であったことが報告されてお り, 埋立てまさ土の密度は，水中においてはかなり高い ことが推察される. 風化の程度を示す尺度となる強熱減 量值 ${ }^{15)}$ は Iwakuni Masado が P.I. Masado の約 2 倍となり Iwakuni Masado の方がより風化が進んでいることが示唆

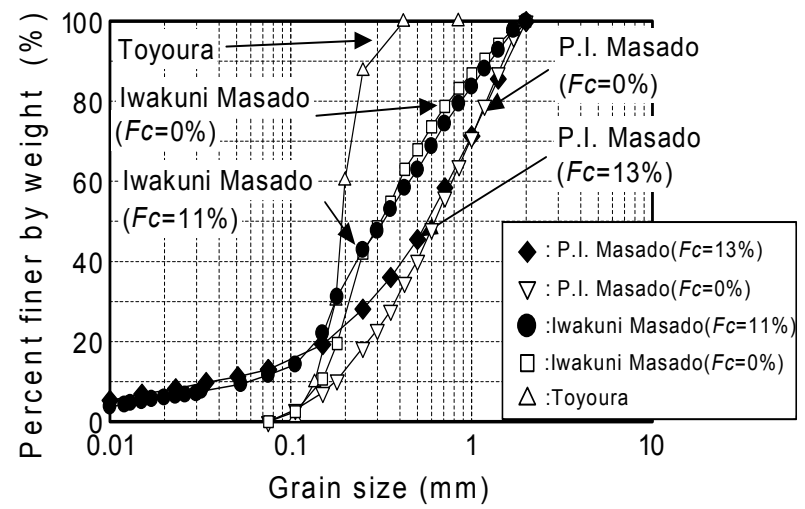

図-1 実験に用いた試料の粒度

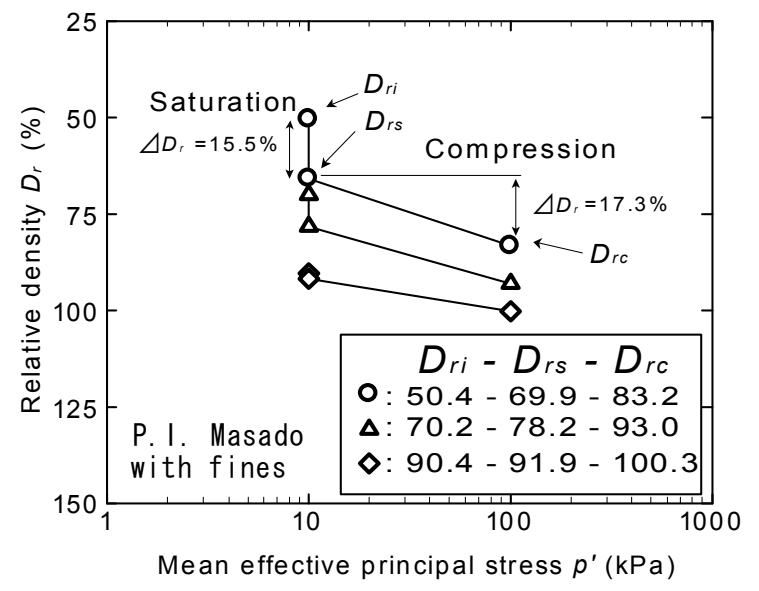

図-2 空中落下漏斗法により作製した原粒度のP.I. Masado供試体 $\left(F_{c}=13 \%\right)$ の水浸および等方圧縮に よる密度の変化

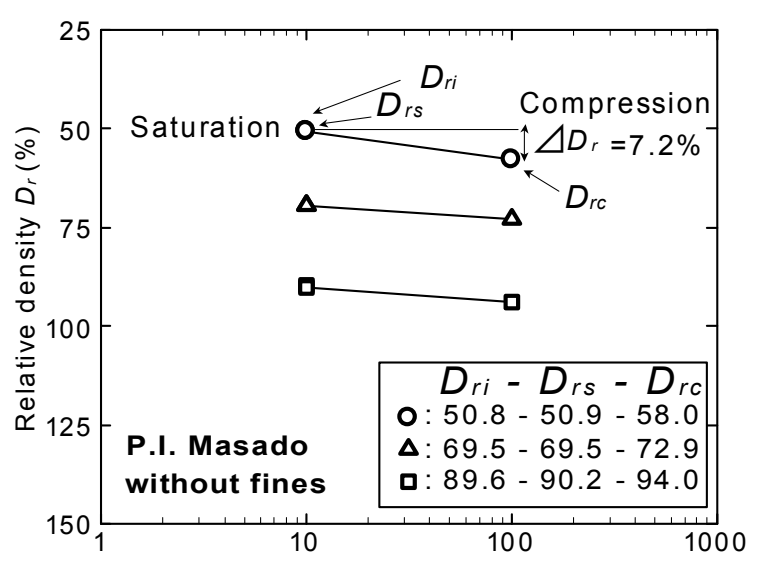

Mean effective principal stress $p^{\prime}(\mathrm{kPa})$

図-3空中落下漏斗法により作製した細粒分を除去し たP.I. Masado供試体 $\left(F_{c}=0 \%\right)$ の水浸および等方圧 縮による相対密度の変化 
される.

三軸供試体は空中落下漏斗法と水中堆積法の 2 通りの 方法により作製した．空中落下漏斗法においては，細粒 分の飛散を防ぐために，気乾状態の試料をモールド内に できるだけ低い位置から落下させ，モールド側壁を木槌 で所定回数打撃を与え所定密度の供試体を作製した．供 試体作製後，二酸化炭素を注入し，脱気水で飽和させ B 值 0.95 以上を確保した。一方，水中堆積法では，これも 細粒分の分離を少なくするため，モールド内に $1 \mathrm{~cm}$ ほど 水を張り，その中に脱気水と混合し 24 時間真空圧を与 えて十分に脱気した試料をスプーンでゆっくり投入して 供試体を作製した。さらに，密度調整のためにモールド 側壁を木槌で所定回数打撃した。また，密な供試体の作 製時には，モールド内の供試体の上に $2.8 \mathrm{~kg}$ の鍾を載せ モールド側面を木槌で打撃した。この方法は，ASTM に よる最大密度試験法 ${ }^{18)}$ に習ったものである.このように 作製した試料に対し，一連の非排水繰返し三軸試験を周 波数 $0.1 \mathrm{~Hz}$ の正弦波の軸荷重を与えることにより行った.

\section{3. まさ土の水浸および等方応力載荷による圧縮 特性}

先にも述べたとおり，まさ土など細粒分を含む材料は， 圧縮性が卓越していることが知られている，原因の 10 は水浸による圧縮であるが，これは，不飽和で十分に締 固められていない地盤に雨水等が浸入することによって サクションが低下し地盤が収縮寸る現象である。この体 積収縮はコラプスと呼ばれる．20目は，粒子が脆弱で あることから有効拘束圧の増加により粒子破砕を伴い, 地盤の圧縮が助長されることである。まず，気乾状態の 試料を空中落下漏斗法で作製した供試体について，供試 体セット時から通水飽和時，等方圧密終了時の間隙比変 化について調べた。

ここで，供試体作製後の間隙比を $e_{i}$, 飽和のための通 水後の間隙比を $e_{s}$, 圧密後の間隙比を $e_{c}$ とした. それぞ れに対応する相対密度も $D_{r i}, D_{r}, D_{r}$ と表示する. 図-2 に 原粒度 P.I. Masado の，図-3 に細粒分を除去した P.I Masado の初期目標相対密度 $D_{n}=50,70 \%, 90 \%$ の供試体の $D_{r}-\log p$ 関係をそれぞれ示す。 まず通水過程においては, 図-2 の原粒度 P.I. Masado では, 初期相対密度 $D_{n}=50.4 \%\left(e_{i}=0.727\right)$ のき，軸方向に平均 $0.16 \mathrm{~cm}(1.6 \%)$, 直 径方向に $0.06 \mathrm{~cm}(1.2 \%)$ 収縮し相対密度減少 $\Delta D_{r}=15.5 \%$ (間 隙比減少 $\Delta e=0.074)$ となった。 それにより飽和供試体の相 対密度は $D_{r s}=69.9 \% （ e_{s}=0.653 ）$ となった。 この通水によ る体積收縮は，初期相対密度が高くなるにつれ減少し， $D_{r}=90.4 \%$ においては，水浸による体積収縮はほとんど生

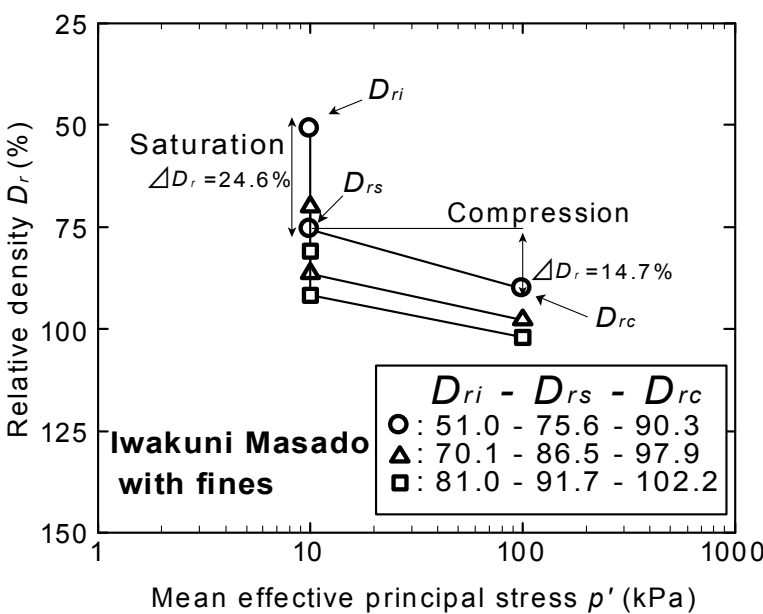

図-4 空中落下漏斗法により作製した原粒度のIwakuni Masado供試体 $\left(F_{c}=11 \%\right)$ の水浸および等方圧縮によ る相対密度の変化

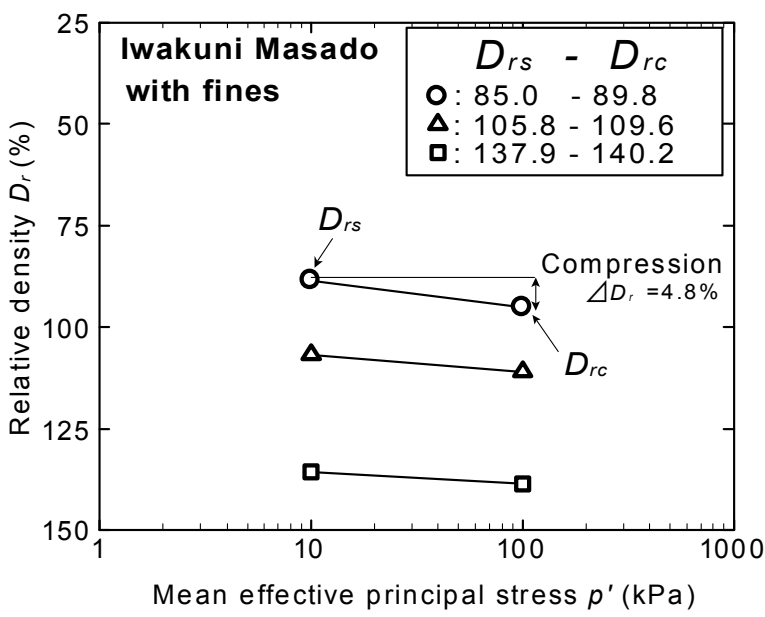

図-5 水中堆積法により作製したIwakuni Masado供試体 $\left(F_{c}=11 \%\right)$ の水浸および等方圧縮による相対密度の 変化

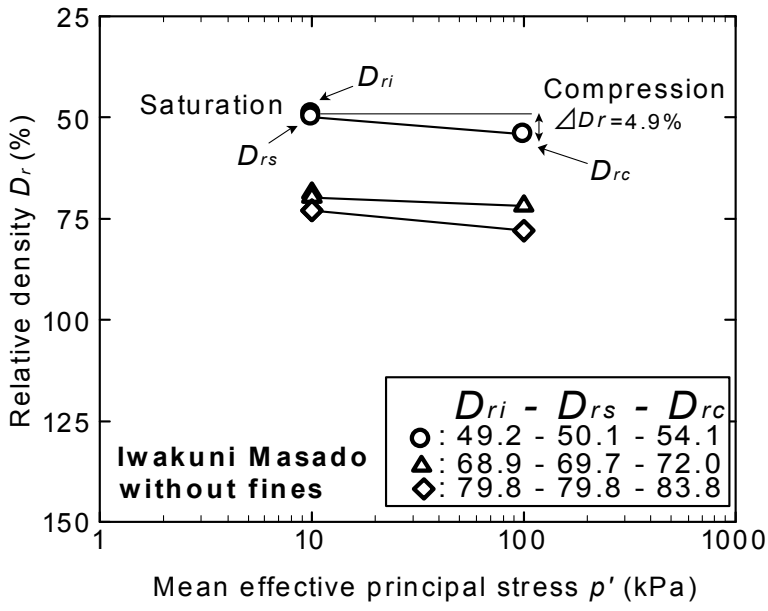

図-6 空中落下漏斗法により作製した細粒分を除去した Iwakuni Masado供試体 $\left(F_{c}=0 \%\right)$ の水浸および等方圧縮 による相対密度の変化 
じていない，次に，等方圧の増加により試料は圧縮する. 図-2 において, $D_{n}=50.4 \%$ の供試体では， $\sigma_{c}=10 \mathrm{kPa}$ から $100 \mathrm{kPa}$ の拘束圧の増加に対して $\Delta D_{r}=17.3 \%$ 程度相対密度 が増加している.

一方，細粒分を除去した試料については図-3 から明ら かなように，水浸による密度増加は，ほとんど生じてい ない，このことより水浸による体積収縮，密度増加は， 細粒分の存在によることが明らかである．また，等方圧 縮においては，細粒分を除去した試料の目標相対密度 $D_{r}=50 \%$ の供試体は原粒試料供試体のそれに比べ約半分 の圧縮量となっている．これは，細粒分を含んだものの 方が構造骨格が弱く圧縮性が高いためと考えられる.

図-4 は，原粒の Iwakuni Masado の空中落下漏斗法によ る，図-5にはその水中堆積法による供試体，図-6には細 粒分を除去し，空中落下漏斗法により作製した試料の $D_{r}-\log p^{\prime}$ 関係をそれぞれ示す．まず，図-4の原粒の Iwakuni Masado の空中落下漏斗法による供試体において は, 原粒の P.I. Masado と同様水浸によって軸方向の沈下, 直径方向の収縮が認められる。 その傾向は相対密度の低 いものほど顕著であり， $D_{n}=51.0 \%$ 供試体では軸方向に $0.25 \mathrm{~cm}(2.5 \%)$ の沈下，直径方向に $0.1 \mathrm{~cm}(2.1 \%)$ の収縮を生 じ，相対密度は $\Delta D_{r}=24.6 \%$ の増加を示している。 また， $\sigma_{c}=10 \mathrm{kPa}$ から $100 \mathrm{kPa}$ までの等方圧の増加に対して $\Delta D_{r}$ $=14.7 \%$ 程度相対密度が増加している. 一方，図-5 には水 中堆積法による結果を示しているが，この方法で密な供 試体作製のためには，供試体の上に錘を置いてモールド 側面を打撃した．原粒の Iwakuni Masado であっても最初 から密な供試体の作製が可能であることが分かる.

また，細粒分を除去した試料では，図-6 に示すように 空中落下漏斗法による Iwakuni Masado においても圧縮量 が大きく減少し，原粒試料に比へ，圧縮量が半分以下と なっている. P.I. Masado と Iwakuni Masado を比較すると, 風化度が高いと考えられる Iwakuni Masado のほうが水浸 および等方圧の増加によるトータルの圧縮量がともに大 きく現れている.

\section{4. 非排水繰返しせん断特性}

P.I. Masado，Iwakuni Masadoについて細粒分の有無，相 対密度, 拘束圧の異なる条件下で一連の非排水繰返しせ ん断試験を行い，液状化強度に及ぼすそれぞれの影響に ついて調べた. 図-7, 8に原粒Iwakuni Masadoの空中落下漏 斗法による供試体における拘束圧，相対密度の異なる試 料の液状化強度曲線を示寸，図-7は，初期目標相対密度 $D_{n}=50 \%$ 一定で，拘束圧 $50 ， 100 ， 150 \mathrm{kPa}$ と変化させたも のであり，図-8は $\sigma_{c}{ }^{\prime}=100 \mathrm{kPa}$ 一定で初期目標相対密度を

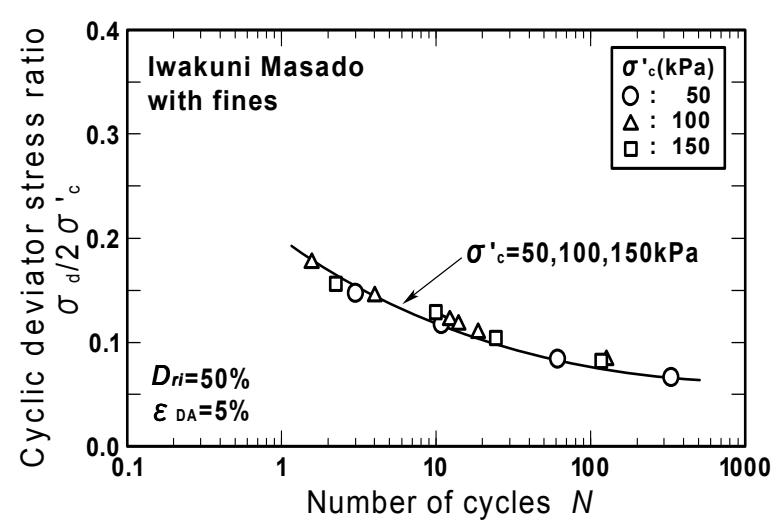

図-7 原粒度Iwakuni $\operatorname{Masado}\left(F_{c}=11 \%\right)$ の非排水繰返しせん 断強度に及ぼす拘束圧の影響

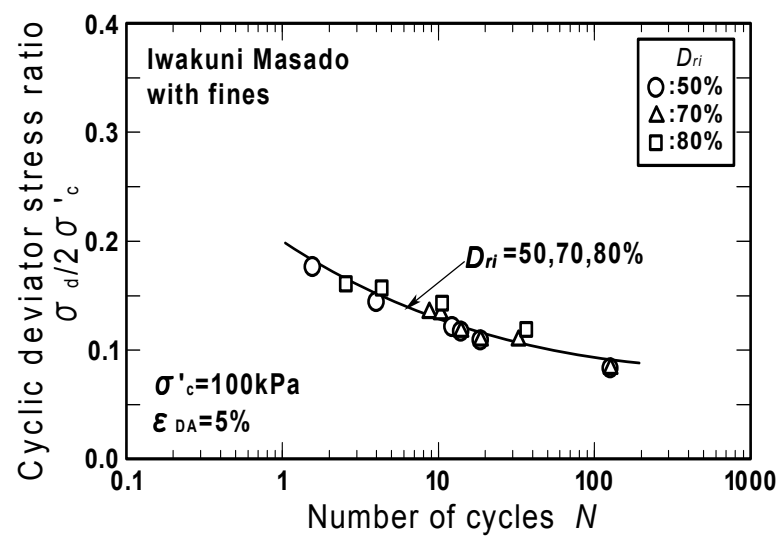

図-8 原粒度 Iwakuni $\operatorname{Masado}\left(F_{c}=11 \%\right)$ の非排水繰返しせ 儿断強度に及ぼす初期相対密度の影響 $\left(D_{i}=50-80 \%\right)$

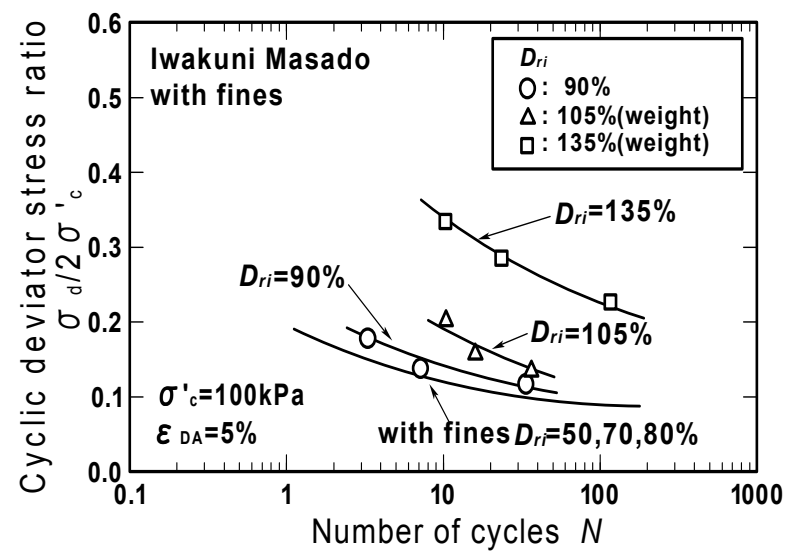

図-9 原粒度Iwakuni Masado $\left(F_{c}=11 \%\right)$ の非排水繰返しせん 断強度に及ぼす初期相対密度の影響 $\left(D_{r}=90-135 \%\right)$

$D_{n}=50 \%, 70 \%, 80 \%$ と変化させた結果を示している．図-7 より初期相対密度が一定の場合，拘束圧の違いによる液 状化強度の違いは見られない，また，図-8において，拘 束圧一定で初期目標相対密度を $D_{n}=50 \%, 70 \% ， 80 \%$ と変 化させた場合においても液状化強度に有意な差は認めら れない，これらは，既往の研究結果 ${ }^{11,911)}$ とも一致する. 


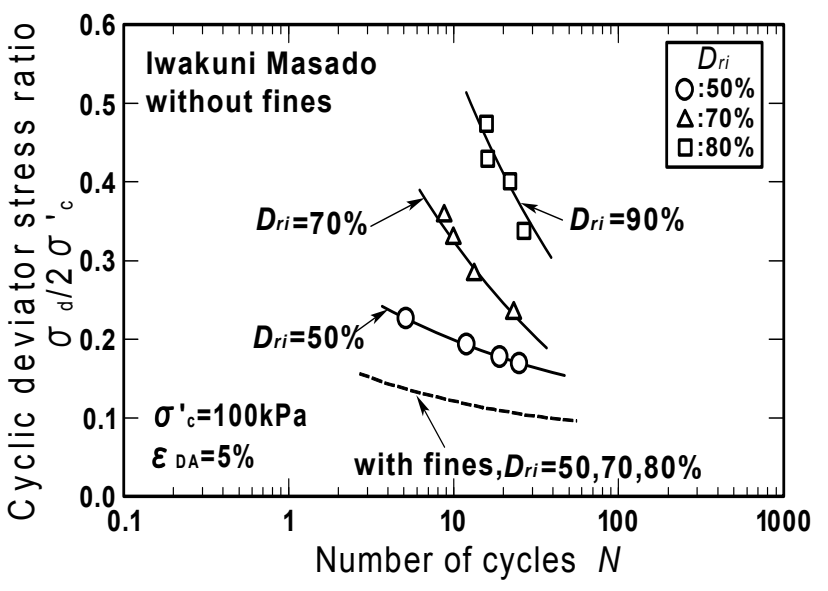

図-10 細粒分を除去したIwakuni $\operatorname{Masado}\left(F_{c}=0 \%\right)$ の非排水 繰返しせん断強度に及ぼす初期相対密度の影響 $\left(D_{r}\right.$ $=50-80 \%$ )

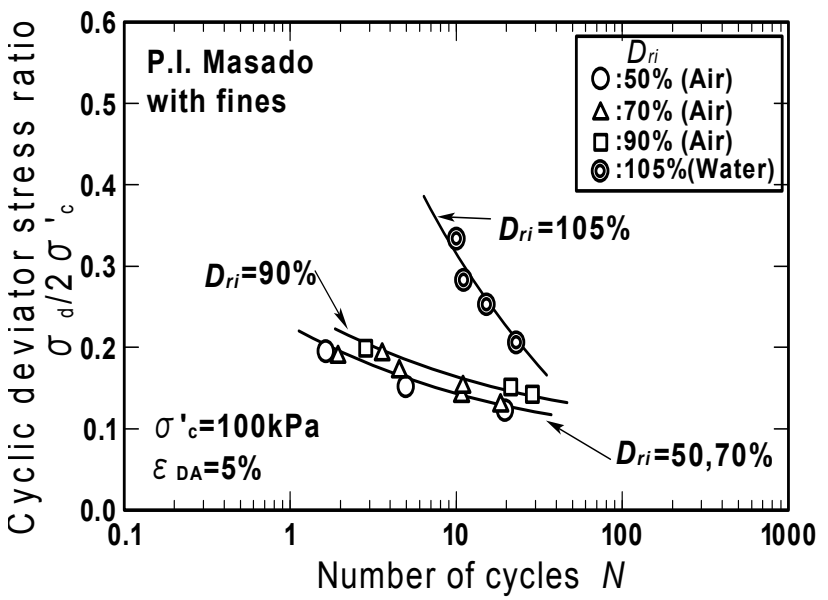

図-11 原粒度P.I. $\operatorname{Masado}\left(F_{c}=13 \%\right)$ の非排水繰返しせん断強 度に及ぼす初期相対密度の影響 $\left(D_{n}=50-105 \%\right)$

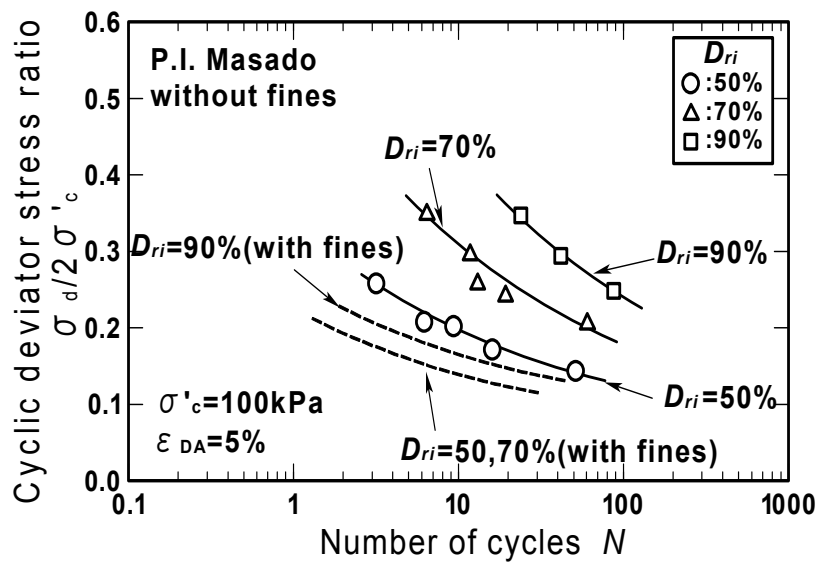

図-12 細粒分を除去したP.I. Masado $\left(F_{c}=0 \%\right)$ の非排水繰返 しせん断強度に及ぼす初期相対密度の影響 $\left(D_{n}=50-90 \%\right)$
これは，空中落下漏斗法により作製した供試体は，初期 目標相体密度 $D_{r i}$ が異なっていても，飽和，圧密過程にお いて体積収縮を起こし，結果的にほぼ同様の相対密度に なったためと考えられる.

図-9に拘束圧 $\sigma_{c}^{\prime}=100 \mathrm{kPa}$ 一定で水中堆積法で初期目標相 対密度を $D_{n}=90 \%, 105 \%, 135 \%$ と変化させた場合の液状化 強度曲線を示す.ここで，いずれのまさ土も水中堆積法 に加えてモールド側壁を木槌で打撃する方法では $D_{n}=90 \%$ が最大の相対密度であったが，供試体上部に $2.8 \mathrm{~kg}$ の錘をのせてモールド側面に打撃を与えることによ り相対密度 $100 \%$ を超える供試体を作製することができ た. 原粒Iwakuni Masadoにおいては $D_{n}=80 \%$ 以下では非排 水繰返しせん断強度に有意な差は認められないが， $D_{n}=90 \%$ を超える辺りから液状化強度が急増する傾向が 認められる。図-10は，細粒分を除去したIwakuni Masado の初期目標相対密度 $D_{n}=50 \%, 70 \%, 80 \%$ における液状化強 度曲線をそれぞれ示したものである，図中に原粒Iwakuni Masadoの結果についても比較のため示している. 細粒分 を除去した試料では初期目標相対密度 $D_{n}=100 \%$ 以下であ っても，相対密度の増加による強度の増加は著しく，初 期目標相対密度を $50 \%$ から $80 \%$ に増加することで，繰返 し回数20回時の液状化強度は約2倍となっている。また， 細粒分の有無で比較すると，同じ相対密度でも細粒分を 除去したものは細粒分を含んだものよりも液状化強度が 高いことがわかる. 図-11に原粒P.I. Masadoの各初期目標 相対密度 $D_{n}=50 \%, 70 \%, 90 \%, 105 \%$ における液状化強度曲 線を示す. ここで， $D_{n}=50 \%, D_{n}=70 \%, D_{n}=90 \%$ は空中落 下漏斗法により作製したものであり， $D_{n}=105 \%$ 供試体は 上に錘を置き水中堆積打撃法によって作製したものであ る. $D_{n}=50 \%, 70 \%, 90 \%$ においてはわずかの液状化強度の 違いしか認められないが，錘を載せて水中堆積打撃法に より作製した試料は $D_{n}=100 \%$ を越え, 液状化強度も著し く増加している. 原粒P.I. Masadoも原粒Iwakuni Masado と 同様に $D_{n}=50 \%$ ～90\%までは液状化強度の差異はあまりな いが初期相対密度が $100 \%$ を超えると液状化強度は急増 する傾向が認められる.

図-12に細粒分を除去したP.I. Masadoの初期相対密度の 異なる試料の液状化強度曲線示す．併せて図中に原粒P.I Masadoの液状化強度曲線も比較として示す. Iwakuni Masadoと同様に細粒分を除去することで夜状化強度は著 しく増加し，相対密度が50\%から90\%に増加することで， 繰返し回数 20 回時の強液状化強度は約 2 倍となっている. また, 細粒分の有無で比較すると, 同じ相対密度でも細 粒分を除去したものは細粒分を含んだものよりも液状化 強度が高いことが明らかである。図-13に $D_{n}=50 \%, 70 \%$, $\sigma_{c}^{\prime}=100 \mathrm{kPa}$ における原粒Iwakuni Masado と原粒P.I. Masadoの 液状化強度曲線の比較を示す. 


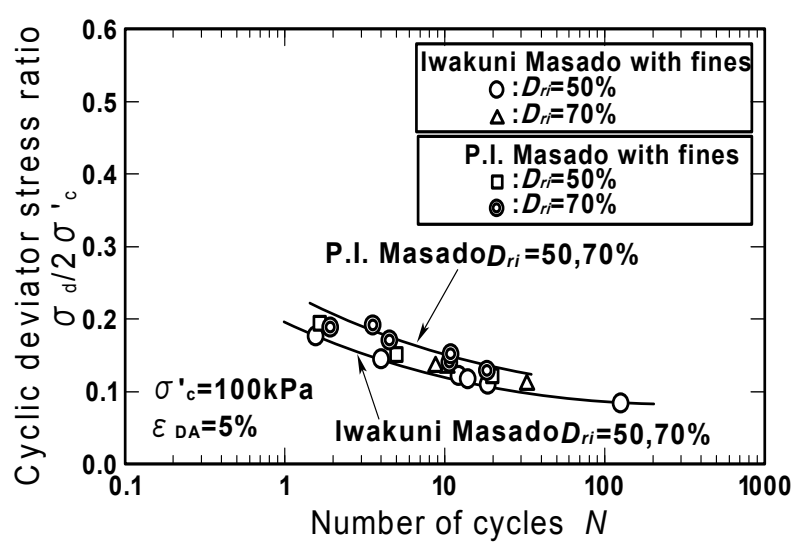

図-13 原粒度Iwakuni Masadoおよび原粒度P.I. Masadoの非排 水繰返しせん断強度

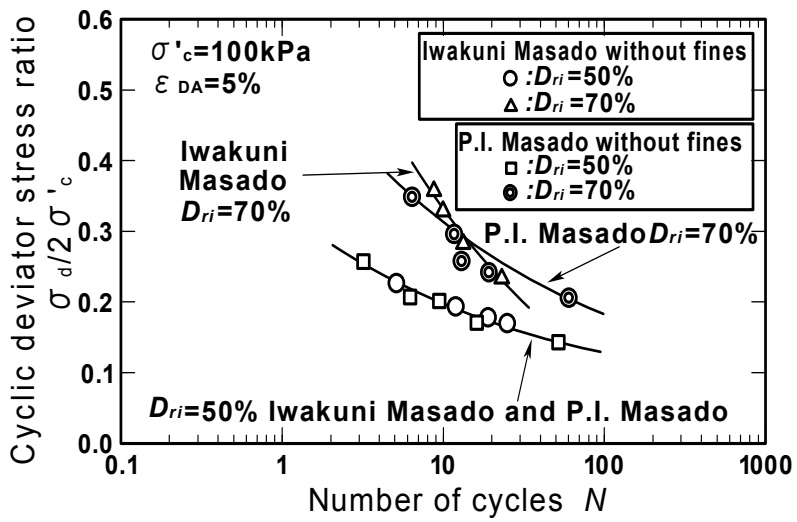

図-14細粒分を除去したIwakuni MasadoおよびP.I. Masadoの 非排水繰返しせん断強度

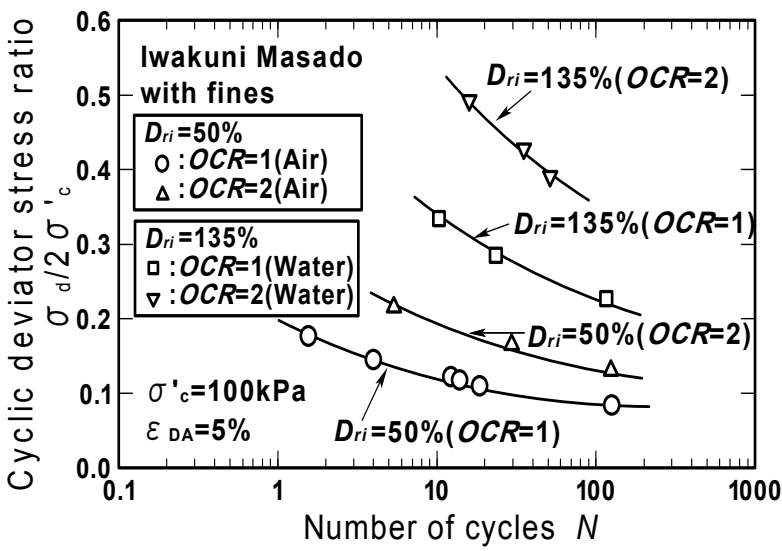

図-15 原粒度Iwakuni Masadoの非排水繰返しせん断強度に
同一相対密度においてはP.I. Masadoの方が，Iwakuni Masadoより液状化強度が高いことが認められる.

図-14に $D_{n}=50 \% ， 70 \%$ ，いずれも細粒分を除去した Iwakuni Masado とP.I. Masadoの液状化強度曲線を示す。い ずれの相対密度においても細粒分を除去した試料の液状 化強度にさほどの違いは見られない。図-15は，原粒 Iwakuni Masado の空中落下供試体および水中堆積供試体 それぞれの液状化強度線を過圧密履歴 $(O C R=2)$ の有無 で比較したものである．過圧密履歴を与えることによっ

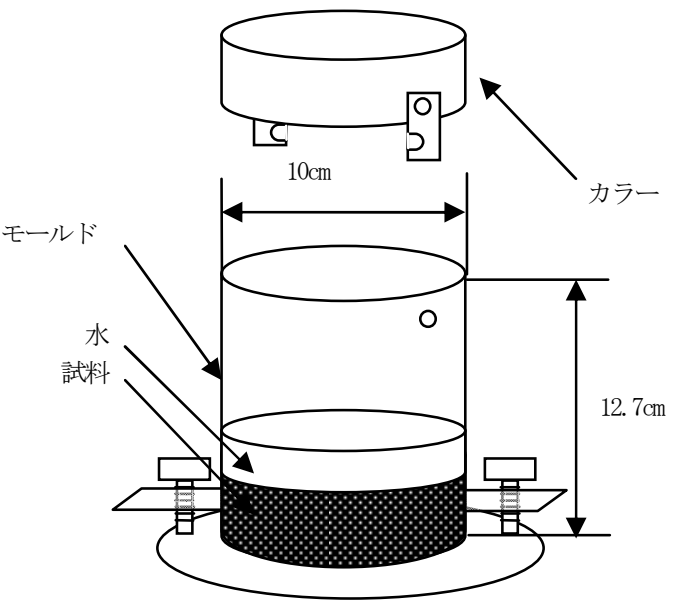

図-16 中型モールドの模式図

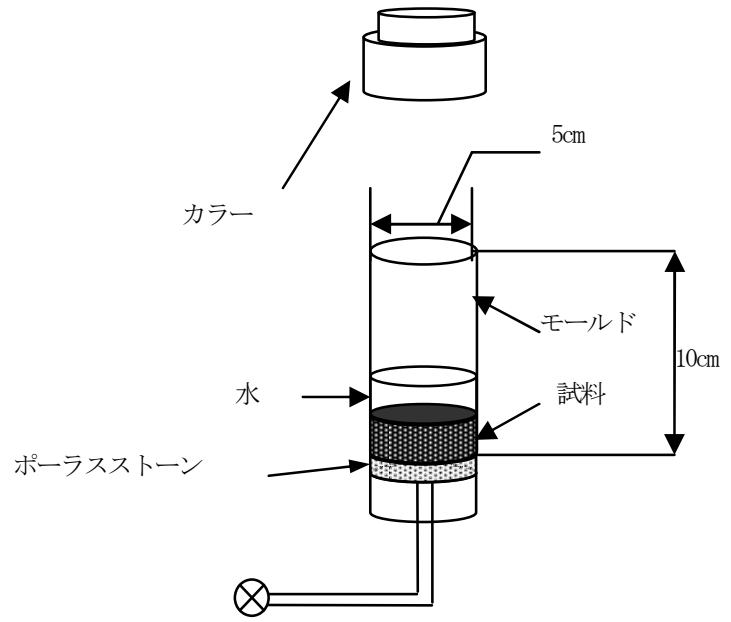

図-17 提案法の模式図 およぼす過圧密履歴の影響

表-2 本研究で用いた最小・最大密度試験方法

\begin{tabular}{|c|c|c|c|c|}
\hline 試験法 & $\begin{array}{c}\text { 試験時の } \\
\text { 土の状態 }\end{array}$ & モ一ルド & 最小密度試験 & 最大密度試験 \\
\hline JIS法 & 乾燥 & 直径 $6 \mathrm{~cm}$, 高さ4cm & 漏斗法 & ハンマーによるモ一ルド側面打撃 \\
\hline ASTM法 & 乾燥 & 直径 $10 \mathrm{~cm}$, 高さ12.7cm & 漏斗法 & ハンマーによるモ一ルド側面打撃 \\
\hline 中型モ一ルド法 & 湿潤 & ASTMと同じ大きさ & スプーン法 & ASTM法と同じ \\
\hline 提案法 & 湿潤 & $\begin{array}{c}\text { 直径 } 5 \mathrm{~cm}, \text { 高さ } 10 \mathrm{~cm} \\
\text { 下部から排水可能 }\end{array}$ & スプーン法 & ハンマーによるモールド側面打撃 \\
\hline
\end{tabular}


て液状化強度は顕著な増加傾向を示している. 空中落下 漏斗法，水中堆積法で瓦いの液状化強度は異なるが，過 圧密履歴による液状化強度の増加率は両者でほぼ同程度 となっている.

\section{5. 細粒分を含むまさ土の最小，最大密度の新たな 評価方法}

相対密度を決定する上での砂の最小，最大密度試験は JISによって定められている．粒径 $2 \mathrm{~mm}$ 以上の碟を含む試 料の最小, 最大密度試験には原ら ${ }^{10,17}$ の提案法があり, この方法は砶分を含む地盤材料の試験法JGS 0132-2000 と して新規に基準化された．しかしながら，前述のとおり， 砂に対する現行のJIS法は細粒分含有率 $5 \%$ 以下の砂質土 が対象とされており，5\%以上の細粒分を有する砂質土 に対しては規定がないまま，現行の方法が用いられてい る現状にある，本研究においても，細粒分を有するまさ 土に現行のJIS法を用いて最小，最大密度を求めて評価 を行ったところ，原粒P.I. Masado，原粒Iwakuni Masado と もに飽和供試体では初期相対密度が100\%を超えるもの も存在する結果となった，細粒分を含むまさ土は，乾燥 状態では不安定な構造を形成し，水浸するとコラプスに より体積収縮を起こすことから，飽和試料の液状化強度 を議論する場合，最小，最大密度も湿潤状態で定義する 必要があると思われる.

そこで，現行の JIS 法，ASTM 法 》も含め，以下の方 法で最小，最大密度試験を行った。現行の JIS 法と ASTM 法はいずれも乾燥試料を対象としたものであるが， モールドの大きさが両者で異なり ASTM 法では内径 $10 \mathrm{~cm}$ ，高さ $12.8 \mathrm{~cm}$ のモールドを用いている。また最大 密度試験において ASTM 法では試料の上に錘を載せてモ 一ルドに打撃を加える点も両者で異なる点である．本研 究では，湿潤試料を対象に ASTM法と同じ寸法のモール ドを用いた場合（以下中型モールド法と呼ぶ）と，内径 $5 \mathrm{~cm}$ ，高さ $10 \mathrm{~cm}$ の三軸供試体作製用の 2 つ割りモールド を用いる場合（以下提案法と呼ぶ）の 2 通りについて試 行した.

まず，最小密度試験について述べる，図-16，17 には 中型モールド法と提案法の試験装置を示す。水で飽和さ れた湿潤状態の試料を締固める場合，図-17 の提案法に 示寸ような排水装置が有効である。しかし，中型モール ド法では，あらかじめ水浸した試料をモールド内に $1 \mathrm{~cm}$ ほど水を張って，その中に落下させる方法で行った．提 案法も中型モールド法と同じ方法で試料を作製した。こ こで中型モールド法と提案法では，最小の密度が得られ るように，試料をできるだけ低い位置からスプーンで水
中にゆっくりと投入した．また上端面処理は，各方法と も最終的に鋭利な直ナイフによりモールド上部の余盛り 部分を取り除くことで統一した。

次に，最大密度試験について述べる．ASTM 法は乾燥 試料を，中型モールド法は湿潤試料を対象とし，いずれ も ASTM の規定に従って締固めを行った。ここでASTM 法と中型モールド法では規定の通り，試料の頂部に質量 $12 \mathrm{~kg}$ の錘を載せて行った。一方提案法では，試料頂部に 載せる錘の質量は，ASTM 法のモールドとの体積比によ り $2.8 \mathrm{~kg}$ とした.さらに締固めは，10 層に分割した試料 を各層ごとにモールドの側面を 40 回打撃することによ って行った. 図-18, 19 は提案法により得られた乾燥密 度と打撃回数との関係を示寸ものである. 図-18，19 と もに，乾燥密度は打撃回数の増加とともに増加し打撃回 数 1000 回では定常に至っている. しかし, 打撃回数 400 回位から乾燥密度のさほどの増加は認められないことか ら, 打撃回数 400 回 で十分に最大密度が得られると判断 した.

図-20，21 は，各試験法により最小密度試験を 5 回行 い，それぞれの回毎に得られた最小密度をプロットした ものである ${ }^{11)}$. Iwakuni Masado は 4 つの試験法で，P.I. Masado は JIS 法と提案法により試験を行った。 図-20に 各試験法より求めた Iwakuni Masado の最小密度を掲げた. 図中乾燥試料を対象とする JIS 法と ASTM 法では，ほぼ 同じ值となっている。一方，湿潤試料を使用する提案法 と中型モールド法では，乾燥試料を扱う JIS 法，ASTM 法に比べ最小密度は高めの值となり, 提案法と中型モ一 ルド法の比較では，中型モールド法の方がより高くなる 結果となった。しかし，中型モールド法ではモールドの 下部から余剩水をうまく排水できないため，試験結果に ばらつきが大きいことがわかる，提案法では下部から余 剩水を排水できるよう改善したため, 結果にばらつきは さほど見られない. 図-21の P.I. Masado についても，提 案法による試験結果にばらつきはほとんど見られない。 これら 4 つの最小・最大密度試験方法を表-2にまとめて 示した.

図-22，23には各試験法により得られた最大乾燥密度 の測定結果を示した．図-22において，Iwakuni Masadoの 各試験法で得られた最大密度を見ると，提案法による結 果が最も大きな值を示している。，一方，中型モールド法 では試料の圧縮時にモールドの下部からうまく余剩水の 排出ができないために試験結果にばらつきが生じている ことがわかる. 図-23のP.I. Masadoにおいては，JIS法と提 案法を比べた場合，提案法による方が最大密度は大きく なっている．図-24に原粒Iwakuni Masadoと原粒P.I. Masado の繰返し回数 20 回時の強度比 $R_{20}$ と JSS法で規定した $100 \mathrm{kPa}$ で圧密後の相対密度 $D_{r c}$ の関係を示寸．豊浦砂の場合は, 


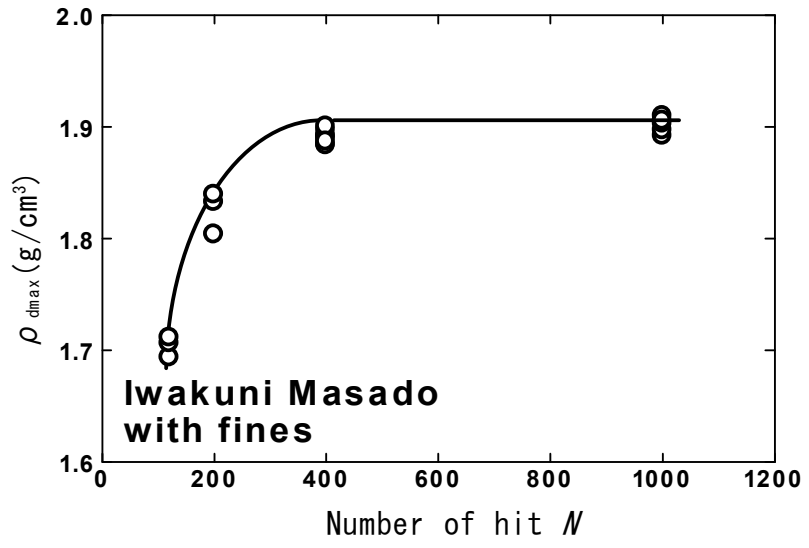

図-18 提案法におけるIwakuni Masadoの最大密度と打撃回 数の関係

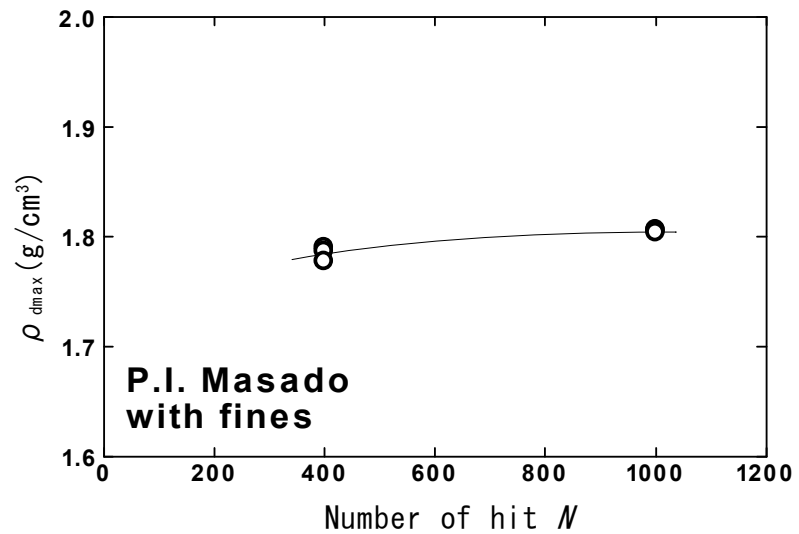

図-19提案法におけるP.I. Masadoの最大密度と打撃回 数の関係

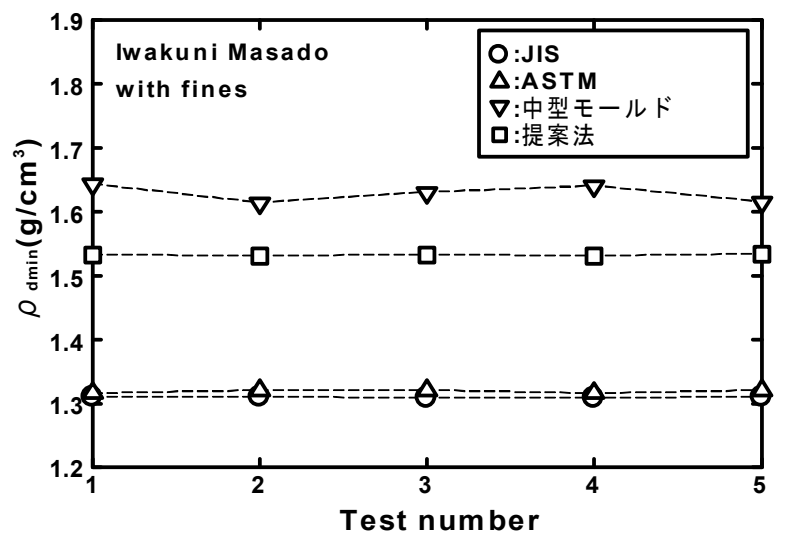

図-20 各方法によるIwakuni Masadoの各試験回での最小 密度

$D_{r c}=80 \%$ 付近までは液状化強度は相対密度に比例して増 加し, さらに $D_{r}=80 \%$ 付近から急激に液状化強度が増加 しているのに対し，Iwakuni Masadoにおいては約 $D_{r c}=100 \%$ を，P.I. Masadoでは約 $D_{r}=90 \%$ を超える付近から液状化強 度が増加する傾向にある。このように，まさ土と豊浦砂 では液状化と相対密度の対応関係が大きく異なっており,

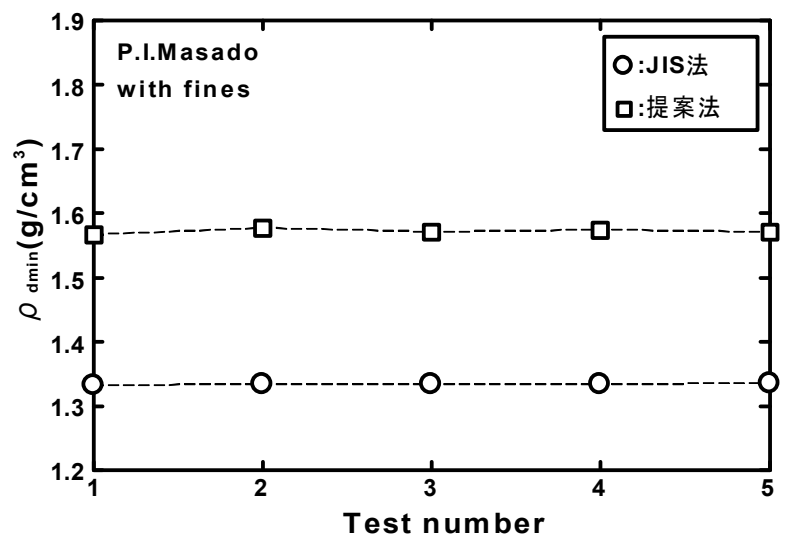

図-21 JIS法と提案法による各試験回での P.I. Masadoの最 小密度

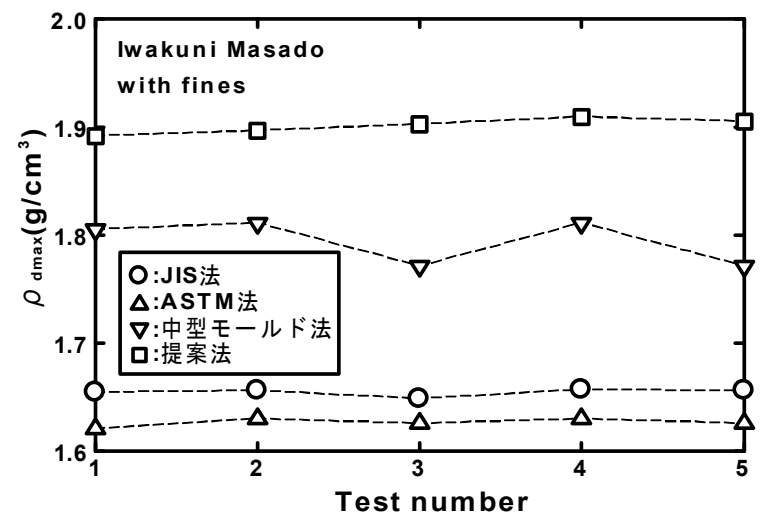

図-22 各方法による各試験回でのIwakuni Masadoの最大 密度

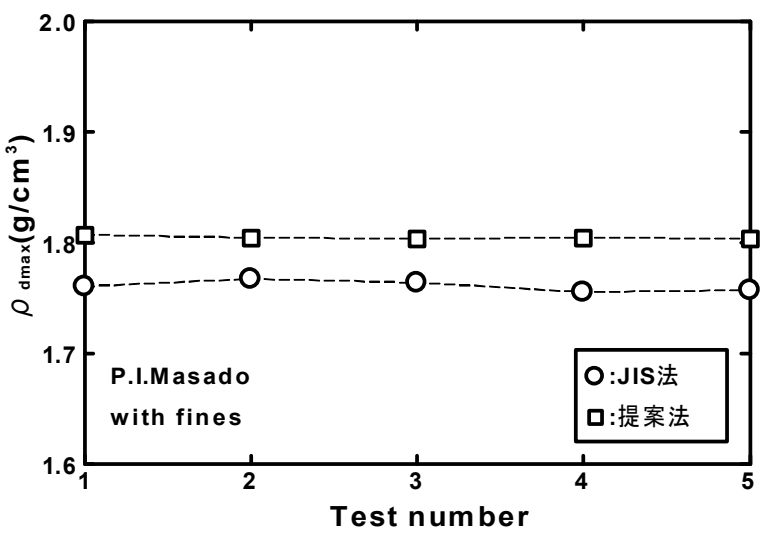

図-23ＪIS法と提案法による各試験回での P.I. Masadoの 最大密度

標準貫入試験の $N$ 值から相対密度を評価し，液状化強度 を推定する方法では大きな誤差が生じることが懸念され る.

図-25に，提案法で得られたまさ土の最大，最小間隙 比を用いて計算した新しい相対密度 $D_{r}{ }^{*}$ を導入し, 繰返 し回数 20 回時の液状化強度比 $R_{20}$ との関係を示した. 図 


\section{6. 結論}

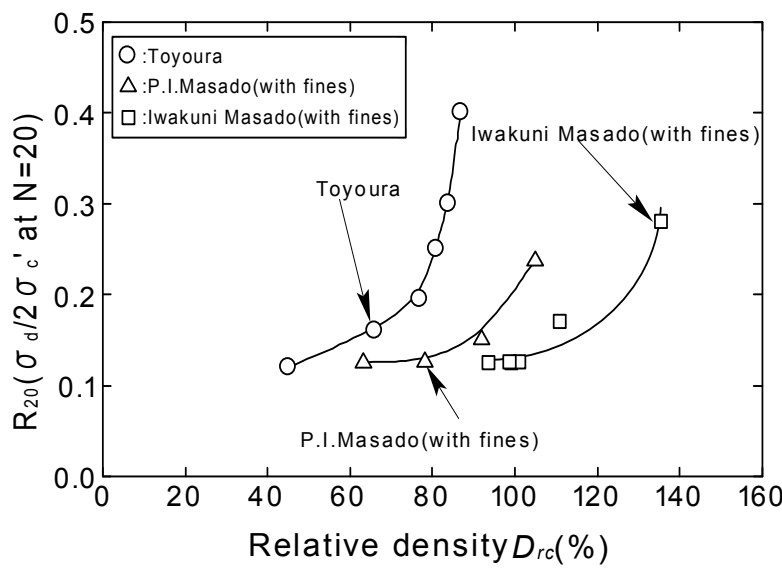

図-24 繰返し回数20回時の非排水繰返しせん断強度比 $R_{20}$ と圧密後相対密度 $D_{r c}$ の関係(JSS法)

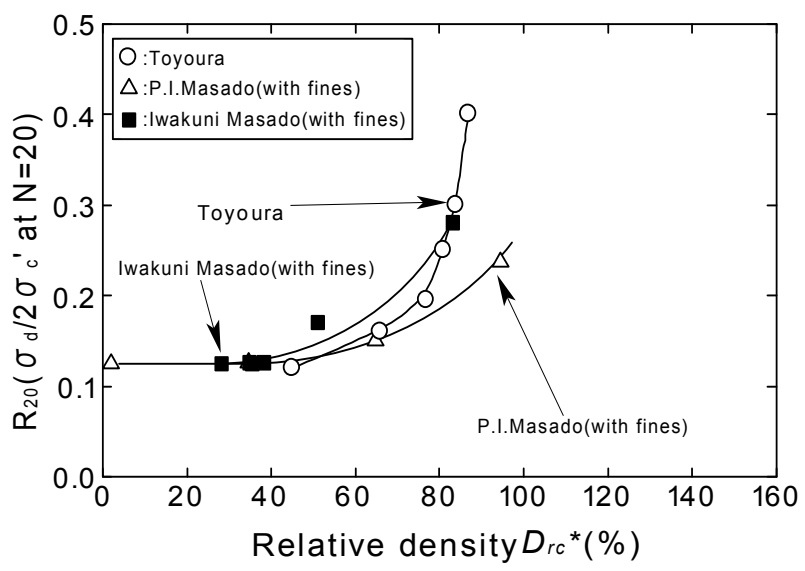

図-25 繰返し回数20回時の非排水繰返しせん断強度比 $R_{20}$ $R_{20}$ と圧密後相対密度 $D_{r c}$ *の関係(提案法)

中豊浦砂の相対密度は JIS 法で求めたものであり，図-24 と同じものである。、ずれの試料の液状化強度曲線もか なり近づき, 液状化強度が急増する相対密度もかなり近 い值となっている．このように，細粒分を有するまさ土 については，提案法による最大最小間隙比から計算した 相対密度 $D_{r}{ }^{*}$ で整理を行うことにより，相対密度 $100 \%$ 以 内で液状化強度の比較を行うことが可能であり， $N$ から 相対密度を通じて液状化強度を評価することが可能であ ると判断される．また，まさ土の埋立て地盤から不擋乱 試料をサンプリングすることは困難であり，再構成試料 による試験しかできないこともあるが，まさ土の水中に おける相対密度 $D_{r i}{ }^{*}$ を推定し試験を実施する必要がある ことが示唆された。
2種類のまさ土を対象に，一連の非排水繰返し三軸圧 縮試験を行い，非排水繰返しせん断強度と相対密度の関 係について検討を行った. 本研究により得られた主な結 論は以下の通りである.

(1) 強熱減量試験の結果 P.I. Masado は 0.932, Iwakuni Masado は 2.257 となり，Iwakuni Masado の方がより風化が 進んでいることが推定される.

(2) P.I. Masado，Iwakuni Masado について原粒度および細 粒分を除去した試料を対象に実験を行ったところ，両ま さ土とも細粒分を含んだものだけが水浸による体積収縮 が確認されるが，細粒分を除去した試料では体積収縮は 起こらない.

（3）細粒分を有するまさ土は細粒分を除去したものより 等方載荷による圧縮量が大きい.

(4)原粒 Iwakuni Masado と原粒 P.I. Masado は，JIS 法による 初期相対密度 50\%〜90\%においては液状化強度に有意な 差は認められない，しかし，水中堆積法で作製した場合， 相対密度が 100\%を超え, 液状化強度も著しく増加する 傾向を示す.

(5)細粒分を除去する事で，P.I. Masado，Iwakuni Masado と も液状化強度は顕著に増加する。

（6）細粒分を含んだまさ土は，過圧密履歴を与えること で顕著な液状化強度の増加が認められる.

(7)細粒分を有するまさ土に対し，水浸し錘を負荷して行 う最小，最大密度試験を提案した。両まさ土に適用し新 しい相対密度 $D_{r}^{*}$ を求めた。 その結果，相対密度 $D_{r}^{*}$ は 100\%以下で定義され，破砕性のない他の砂等とも同等 の尺度で液状化強度を比較することが可能となった.

\section{参考文献}

1) 風間基樹, 加賀谷俊和, 柳澤栄司:まさ土の液状化 抵抗の特殊性，土木学会論文集，No.645/III-50, pp.153-166, 2000.

2) 兵動正幸，荒牧憲隆，岡林巧，中田幸男，村田秀 一：破砕性土の定常状態と液状化強度, 土木学会論 文集，No.554/III-37,pp.197-209, 1996.

3) 黄大振，柳沢栄司，菅野高弘：シルトを含む砂のせ ん断特性について，土木学会論文集，No.463/III-22, pp.25-33, 1993.

4) Hyodo, M., Hyde, A. F. L. and Aramaki, N.: Liquefaction of crushable soils, Geotechnique, No.4, pp.527-543, 1998.

5) 中山義久, 西田一彦, 西形達明, 井上啓司 : まさ土 の物性と液状化特性，土木学会論文集，No.638/III-49, pp.207-215, 1999.

6)亀井健史, 榎本雅夫 : 締固めたシルト質土の水浸に 伴うコラプス沈下挙動，土木学会論文集，No.505/III29, pp.97-103, 1994.

7) 亀井健史, 榎本雅夫 : 土の粒度の違いが締固めた土 のコラプス沈下量に及ぼす影響，土木学会論文集， 
No.535/III-34, pp.65-72, 1996

8) 福島伸二，望月美登志：神戸人工島における埋立土 の液状化特性に及ぼす密度, 拘束圧の影響, 土木学 会論文集，No.687/III-56，pp.49-64， 2001.

9）兵動正幸，荒牧憲隆，徳原裕輝，菊地慎二，中田幸 男，村田秀一：六甲アイランド埋立てまさ土の非排 水繰返しせん断特性，土木学会論文集，No.582/III-41， pp.87-98, 1997.

10）佐藤正行，小田寛，風間英彦，小瀬木克己：細粒分 が埋立地盤の液状化特性に及ぼす影響に関する基礎 的研究，土木学会論文集，No.561/III-38, pp.271-282, 1997.

11）金佑泰，兵動正幸，中田幸男：まさ土の繰返しせん 断特性に及ぼす細粒分の影響, 第 57 回土木学会中国 支部研究発表会，III-33,pp.261-262, 2005.

12）中山義久, 西田一彦, 西形達明, 井上啓司：まさ土 の物性と液状化特性，土木学会論文集，No.638/III-49, pp.207-215, 1999.

13) (社)地盤工学会 : 土質試験の方法と解説，第 8 章 砂の 最小，最大密度試験，pp.136-145, 2001.

14) Inagaki, H., Iai, S., Sugano, T., Yamazaki, H. and Inatomi, T.: Performance of caisson type quay walls at Kobe Prot, Special Issues of Soils and Foundations, pp.119-136, 1996.

15）村田秀一, 兵動正幸, 安福規之: 風化度に着目した 乱さないまさ土の圧縮, せん断特性, 土木学会論文 集，No.382/III-7, pp.131-140, 1987.

16）原忠, 吉田次男, 田中昌廣, 國生剛治：試験方法の 違いが砂礫の最小, 最大密度に与える影響, 第 38 回 地盤工学研究発表会, pp.565-566, 2003.

17) 原忠, 國生剛治：砂砅の最大密度に及ぼす影響因子 の分析, 土木学会論文集, No.778/III-69, pp.151-162, 2004.

18) ASTM: Relative Density of Cohesionless Soils, STP No.523, 510 pp., American Society for Testing and Meterials D4253-83, D4254-83, 1973.

\title{
ROLE OF FINES ON UNDRAINED CYCLIC SHEAR STRENGTH AND RELATIVE DENSITY OF DECOMPOSED GRANITE SOIL "MASADO”
}

\author{
Woo-Tae KIM, Masayuki HYODO, Yukio NAKATA, Norimasa YOSHIMOTO \\ and Shohei NODA
}

\begin{abstract}
A series of undrained cyclic triaxial tests was performed on reconstituted decomposed granite soil Masado sampled from two sites. The liquefaction strengths of these Masado were almost constant when the relative density was less than $80 \%$ and they increased markedly when the relative density exceeded $100 \%$. This was believed to be due to the fact that the relative densities were calculated based on conventional minimum and maximum density tests specified for clean dry sands whereas Masado contains non-plastic fines and volume reduction occurred during saturation. In the present study, minimum and maximum density tests were carried out using wet samples and the results were used to redefine the new relative density of the material. The relationship between liquefaction strength and the redefined new relative density showed good correlation, with Masado showing similar trend in behavior with relative density as Toyoura sand. With the proposed method of using a re-defined relative density, a better understanding of the relation between liquefaction strength and relative density of decomposed granite soil containing fines was obtained.
\end{abstract}

